Western University Scholarship@Western

Centre for the Study of International Economic

Centre for the Study of International Economic

Relations Working Papers

Relations

1987

\title{
Two-Country Trade Liberalization in an Address Model of Product Differentiation
}

Nicolas Schmitt

Follow this and additional works at: https://ir.lib.uwo.ca/economicscsier_wp

Part of the Economics Commons

Citation of this paper:

Schmitt, Nicolas. "Two-Country Trade Liberalization in an Address Model of Product Differentiation." Centre for the Study of International Economic Relations Working Papers, 8718C. London, ON: Department of Economics, University of Western Ontario (1987). 
ISSN $\quad 0228-4235$

ISBN $\quad 0-7714-0951-6$

THE CENTRE FOR THE STUDY OF INTERNATIONAL ECONOMIC RELATIONS

WORKING PAPER NO. $8718 \mathrm{C}$

TWO-COUNTRY TRADE LIBERALIZATION IN AN ADDRESS

MODEL OF PRODUCT DIFFERENTIATION

Dopuriment of Economics Library

Nicolas Schmitt

JAN 111988

Hnivaring of Waman Enturio

This paper contains preliminary findings from research work still in progress and should not be quoted without prior approval of the authors.

DEPARTMENT OF ECONOMICS

THE UNIVERSITY OF WESTERN ONTARIO

LONDON, CANADA

N6A $5 \mathrm{C} 2$ 


\section{TWO-COUATRY TRADE LIBERALIZATION IN AN ADDRESS}

MODEL OF PRODUCT DIFFERENTIATION

by

Nicolas Schmitt

University of Western Ontario

December 1987

Abstract

This paper investigates the effects of reciprocal tariff reductions in a two-identical country model of product differentiation. It makes three points. First, the existing results about market structure effects of trade liberalization can easily be derived from a one-dimensional characteristic space model in which the prohibitive tariff rate is endogeneously determined. Secondly, these effects depend crucially on the initial ad valorem tariff rate and on the elasticity of the individual demand. Thirdly, reciprocal tariff reductions alone do not necessarily warrant welfare gains.

JEL classification: $411,420,423$

Keywords: Intra-industry trade, tariff, trade liberalization, market structure, welfare

Mailing Address: Department of Economics

Social Science Centre

University of Western Ontario

London, Ontario N6A $5 C 2$

Canada

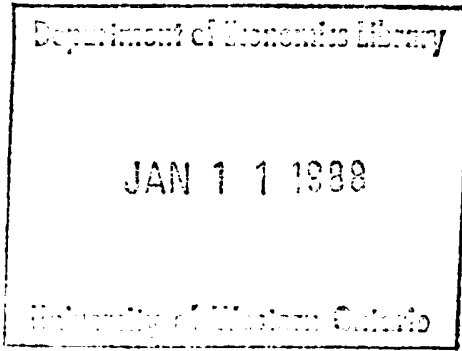




\section{Introduction}

The purpose of this paper is to analyse the market structure as well as the welfare effects of small reciprocal tariff reductions between two identical countries in a simple characteristic space model of intra-industry trade.

Surprisingly, despite an abundant literature on intra-industry trade, there are very few papers directly dealing with this question and virtually none are set in a characteristic space approach. In effect, most of the existing models in the intra-industry trade approach (Krugman (1979, 1980, 1981), Lancaster (1980), Helpman (1981), Dixit and Norman (1980), Lawrence and Spiller (1983)) derive results without explicitly introducing barriers to trade. In addition when they do contain barriers to trade, the analysis often deals with unilateral changes in commercial or in other public policies (Venables (1982), Lancaster (1984)).

A short review of some of the conclusions about market structure and welfare effects of tariff cuts in differentiated product industries as well as a discussion of the methodology adopted by most authors will help to understand what may be missing in the current literature.

Even though different preference structures are used to introduce product diversity, ${ }^{1}$ existing models in the intra-industry trade approach tend to reach similar conclusions about the market structure effects of opening trade. The integration of two identical economies is accompanied by a less than proportional decrease in the number of domestic products, an increase in the quantity produced of the remaining goods, and a decrease in their equilibrium price. As compared with no trade, free trade is therefore welfare improving because of gains from economies of scale and from increased product diversity 
(Dixit and Norman (1980), Krugman (1979)).

Although these results are appealing, they are based on the comparison of the no-trade and the free-trade equilibrium. Given that trade liberalization is typically progressive and takes place between countries which already have trade relationships, it would seem more interesting to consider freer trade from an equilibrium in which trade already occurs. The comparison of two isolated and extreme equilibria simplifies the analysis but the results cannot necessarily be extended to the effects of small tariff reduction. It is a useful simplification only if one can show that, whatever the initial equilibrium, reciprocal tariff reductions induce similar changes in market structure and in welfare. This demonstration is not possible without explicitly introducing barriers to trade. In addition, without them, the no trade situation is purely artificial since it can only arise from governmental trade prohibition. No-trade equilibria are more interesting when they result from the structure of the market.

Yodels that analyse commercial policies in differentiated product industries generally conclude that unilateral interventions away from free trade is welfare improving (Venables (1982), Lancaster (1984)). The imperfect nature of the market equilibrium explains this result. Only two studies help to understand the welfare effects of bilateral trade liberalization. Horn (1984) compares the market equilibrium with the optimum number of products and firm production by varying the size of the economy. Assimilating this experiment to trade liberalization, he analyses the scope for public intervention consisting of either controlling the number of products or the firm production. He discovers that there is an optimal finite size of the 
economy at which the market equilibrium number of products corresponds to the first-best optimum. Horn's model indicates that a change in the size of the country (or freer trade) can always result in the first-best number of products and firm production if regulatory policy intervenes to correct output and/or the number of firms when the market equilibrium does not bring the first-best solutions. Venables (1985) looks at custom unions and reports that the formation of a union unambiguously raises welfare of all members when countries are symmetric. There is thus a good presumption in favor of complete trade liberalization with or without public policies in these models of intra-industry trade. However, both use the non-address approach to product differentiation (or Dixit and Stiglitz (1977)'s approach).

There are therefore two issues which need further investigation. First, the market structure effects of small tariff reductions has yet to be proposed. Secondly, the welfare results must be strengthen by considering other approaches to product differentiation.

In order to investigate these two issues, this paper considers a simple address model of product differentiation with an explicit barrier to trade between two identical countries (or markets). Each market is represented by a one-dimensional characteristic space in the Hotelling (1929)'s tradition and the barrier to trade is an ad valorem tariff rate levied on the imports of both countries in this line of products ${ }^{2}$.

Products are defined by their address (or co-ordinates) in some continuous support. This approach captures attractive consumer's as well as producer's features (see Archibald, Eaton and Lipsey (1986)). In contrast to the non-address approach, each consumer buys a single product (or characteristic) with choice depends upon preferences and product prices. As a 
result, the elasticity of substitution between pairs of products depends on how far apart the characteristics of the products are.

This paper shows that, even if one can replicate the existing results by comparing the equilibrium at the endogeneously determined prohibitive rate with the equilibrium in free trade, one cannot infer from these results what would happen on market structure and welfare if tariff reductions occurred from non-prohibitive rates.

The intuitive explanation of this result is simple. When firms sell in both the domestic and the foreign markets, reciprocal tariff reductions usually decrease profits because the markup on domestic sales decreases and domestic sales count for the largest share of total sales. But, with ad valorem rates, this effect is not symmetric as tariff cuts increase more the markup on foreign sales than they decrease it on domestic sales. Therefore, bilateral trade liberalization increases firm profits provided that the shares of domestic and foreign sales are not too far apart. This is the case when tariff rates are relatively low.

This result has important implications on the market structure effects of trade liberalization, since, when the initial rates are low, tariff reductions are shown to induce entry and lower scale of production.

The welfare implications of this result are also interesting. A crucial aspect of welfare in differentiated product industries is whether the market bring too few or too many products with respect to the socially optimal number. Market equilibria in address models of product differentiation notoriously bring too many products with respect to the optimum. This model is no exception. Hence, freer trade alone, may not be desirable as it induces entry of new firms, even if these new products increase product diversity. 
Looking at optimal policies accompanying tariff reductions, the superiority of free trade is reestablished if both countries adopt the same production tax. The remainder of this paper is organized as follows. In the next section, the two-country model with ad valorem tariff rate is specified. The restricted trade equilibrium and its two limiting solutions (free trade and no trade) are then derived. Section 3 analyses the comparative statics properties of the model and section 4 considers its welfare implications. Finally, Section 5 summarizes the main results.

\section{The Model}

The model involves two identical countries (Country I and II) trading differentiated products subject to a reciprocal ad valorem tariff rate ( $t$ ) levied on the net import price. By assumption, both countries always levy the same tariff rate.

An explicit two-country model is needed because a change in the tariff rate affects the relative price of the imported with respect to the domestic products. It is therefore assumed that the set of all possible brands is represented in each country by the real line. Any brand $i$ is completely defined by a point (or characteristic) on this line $\left(x_{i}\right)$ and by its price.

The preferences of any consumer located in any country are captured by $u\left(v, y, x_{i}, x^{*}\right)= \begin{cases}0 & \text { if } v<1 \\ y-\left|x_{i}-x^{*}\right| & \text { if } v \geq 1,\end{cases}$ where $y$ represents the numeraire good (whose price is 1 ) and $v$ the quantity demanded of brand $i$. The location $x^{\star}$ can be interpreted as the consumer's most preferced characteristic, since utility is maximized when $x^{\star}$ corresponds 
to the available brand characteristic $\left(x_{i}\right)$. The consumer's demand is thus perfectly price inelastic such that

(2) $v= \begin{cases}0 & \text { if } s_{i}>I-\left|x_{i}-x^{*}\right| \\ 1 & \text { if } s_{i} \leq I-\left|x_{i}-x^{*}\right|,\end{cases}$

where $I$ is the consumer's income and $s_{i}$ is the mill price of the consumer's best available brand. By assumption, I is sufficiently large so that one unit is always demanded. It is further assumed that, in both countries, there is the same uniform distribution of consumers along the real line represented by the density D. It is apparent from (2) that the income elasticity of the differentiated product is zero, so that the redistribution of the tariff revenues to the consumers only affects the demand for the numeraire product. Its role can thus be disregarded. Complete inelasticity of the individual demands at one unit should not be considered as highly restrictive; it represents a useful approximation for many differentiated products (automobile, appliances). Relaxation of this assumption however is also considered.

Each firm is assumed to produce a single brand and its costs of production $C(Q)$ are independent of the characteristic of the brand:

$$
C(Q)=C Q+K \quad C>0, K>0,
$$

where $Q$ represents the total production of each firm, $K$ is a fixed cost of production and $c$, a constant marginal cost. Since costs are not brand specific, firms can costlessly relocate their brand in the product space. It is assumed, however, that firms cannot change the geographical location of 
their production and thus can sell their product in the foreign market through exports only.

Therefore, the model is essentially a partial equilibrium model since there is no explicit link between consumer's income and factor payments. Its simple structure however makes it possible to anlayse the interactions between market structure and tariff.

The Restricted Trade Equilibrium

Consider the symmetric equilibria only and assume that the tariff rate is consistent with trade. In a one-dimensional characteristic space model, any brand $i$ directly competes with two brands, $i-1$ and $i+1$, in both the domestic and the foreign markets. Concentrating on the demand for brand $i$ in its domestic market, it depends upon prices $s_{i}, s_{i-1}, s_{i+1}$ and the reciprocal tariff rate $t$. At the market

boundary between $i$ and $i+1$, there is a consumer with most preferred brand $\bar{x}$ who is indifferent between the two available brands. Given the preference structure and, knowing that $L$ represents the distance in the characteristic

space between any adjacent products, $\bar{x}$ is defined by ${ }^{3}$

$$
\bar{x}=\frac{1}{2}\left(s_{i+1}-s_{i}\right)+x_{i}+\frac{L}{2}
$$

All consumers with most preferred characteristic $x^{*}$ such that

$x^{\star}<\bar{x}$ prefer brand $i$ to $i+1$. Similarly, the boundary between brand $i$

and $i-1$ is defined by

$$
\hat{x}=\frac{1}{2}\left(s_{i}-s_{i-1}\right)+x_{i}-\frac{L}{2}
$$

where all consumers with preferences $x^{\star}>\hat{x}$ prefer brand $i$ to $i-1$. The 
extent of the market for brand $i$ is $\bar{x}-\hat{x}$, and since each consumer buys one unit of the differentiated product, the demand for brand $i$ in its domestic market is $D(\bar{x}-\hat{x})$ or

(4)

$$
Q D_{i}\left(s_{i-1}, s_{i+1}, s_{i}, t\right)=\frac{D}{2}\left(s_{i+1}+s_{i-1}-2 s_{i}+2 L\right) \text {. }
$$

Similarly, the demand for brand $i$ in its foreign market is

$$
\left.Q F_{i}{ }^{*} s_{i-1}, s_{i+1}^{*}, s_{i}^{*}, t\right)=\frac{D}{2}\left(s_{i-1}^{*}+s_{i+1}^{*}-2 s_{i}^{*}+2 L\right) \text {. }
$$

The gross profit, defined as the excess of revenues over variable costs, of the firm selling brand $i$ domestically and abroad is then

$$
R_{i}\left(s_{i-1}, s_{i-1}^{*}, s_{i}, s_{i}^{*}, s_{i+1}, s_{i+1}^{*}, t\right)=\left(s_{i}-c\right) Q D_{i}+\left(\frac{s_{i}^{*}}{1+t}-c\right) Q F_{i} .
$$

With third party international arbitrage assumed impossible, firm i, contemplating exporting, naturally perceives the domestic and the foreign markets as two separate entities for which distinct price decisions should be made. The first-order profit-maximizing conditions in a symetric arrangement when firm i takes other prices as given are

$$
\frac{\partial R}{\partial s_{i}}=s_{i+1}+s_{i-1}-4 s_{i}+2 c+2 L=0 \text {, }
$$

$$
\frac{{ }_{i}}{\partial\left(s_{i}^{*} / 1+t\right)}=s_{i+1}^{*}+s_{i-1}^{*}-4 s_{i}^{*}+2 c(1+t)+2 L=0 .
$$

(Inspection of (7) and (8) indicates that the second-order conditions are satisfied). The solutions of the system of first-order conditions depend on the product configuration of the market. 
Proposition 1. When products can be costlessly relocated in the characteristic space, the interleaved product arrangement (i.e., each domestic product competes directly with two imported products) is the only symmetric equilibrium in characteristics for the entire set of reciprocal tariff rates consistent with this arrangement.

Proof. See Appendix A. II

To derive this result, it is assumed that firms take prices and characteristic of other products as given subject to no price undercutting. This modified zero-conjectural variation eliminates the absurd result that undercut firms do not react when their profits become negative and ensures that an equilibrium exists (Novshek (1980)).4

Given the result of Proposition 1, this paper deals only with the interleaved arrangement, which is illustrated in Figure 1.

Figure 1

In this configuration, all the firms are identical. There is thus a unique set of equilibrium prices for the domestic products $\left(p_{e}\right)$ and the foreign products $\left(q_{e}\right)$. The domestic prices are such that $p_{e}=s_{i}=s_{i+1}^{*}=$ $s_{i-1}^{*}$ and the foreign prices such that $q_{e}(1+t)=s_{i}^{*}=s_{i+1}=s_{i-1}$, where, using (7) and (8),

(9) $\quad p_{e}=L+c\left(1+\frac{t}{3}\right)$,

(10) $q_{e}(1+t)=L+c\left(1+\frac{2}{3} t\right)$.

These equilibrium prices indicate that the net import price is lower than the domestic price as long as the tariff rate is positive. Since both 
countries levy the same tariff rate, this constitutes an example of the so-called reciprocal dumping phenomenon (Brander and Krugman (1983)). The existence of a non-prohibitive tariff makes the net foreign demand for any product more elastic than its domestic demand, inducing firms to set a lower price abroad than at home when they have latitude to price discriminate. Using (4) and (5), the equilibrium demand for any product in the domestic and the foreign markets is, respectively,

(11) $Q D(D, L, C, t)=D\left(L+\frac{1}{3} c t\right)$,

(12) $Q F(D, L, C, t)=D\left(L-\frac{1}{3} c t\right)$.

Not surprisingly, inelastic individual demands make the total demand for any product independent of the tariff rate.

The equilibrium gross profit of the representative firm selling its brand in both markets $R(D, L, C, t)$ is equal to the sum of its domestic (RD) and foreign (RF) gross profit:

(13) $R(D, L, C, t)=R D(D, L, C, t)+R F(D, L, C, t)$

$$
=D\left(L+\frac{1}{3} c t\right)^{2}+\frac{D}{1+t}\left(L-\frac{1}{3} c t\right)^{2}
$$

The costless product relocation assumption ensures that the incumbent firms do not benefit from a first-mover advantage over the entrants. Any pure profit represents therefore an invitation for entry so that the market equilibrium occurs when the representative firm earns no pure profit. 5 
In a symmetric equilibrium, this condition makes the distance between any adjacent products endogenous to the model. Hence, the market area ( $\underline{L}$ ) for which no pure profit is earned is such that

(14) $R(D, \underline{L}, C, t)-K=0$.

Instead of considering $L$ as the endogenous variable, it is often more convenient to look at the number of products per unit of characteristic space. Given the interleaved arrangement, the number of domestic products per unit of characteristic space is then defined as $n=1 /(2 L)$.

\section{Free Trade and Mo Trade}

The model has two limiting solutions: free trade and no trade. They are limiting solutions because the interleaved market arrangement ceases to be relevant.

A restricted trade equilibrium exists as long as the representative firm finds it profitable to export. Specifically, it exports as long as its foreign gross profit (RF) is positive. Hence, given (13), the representative firm exports as long as $t<t_{p}$, where,

(15) $t_{p}=3 \frac{\mathrm{L}}{\mathrm{c}}$.

A prohibitive tariff rate can be defined as a rate which not only eliminates trade between two countries but which also suppresses all competition between the foreign and the domestic products whatever the set of goods produced by the foreign country.

Proposition 2. The tariff rate $t_{p}=3 \mathrm{~L} / \mathrm{c}$ is the prohibitive tariff rate of the interleaved product arrangement.

Proof. First, with (10), $t=t$ implies $q_{p}-c=0$ and, using (12), $Q F=0$ for 
any foreign product whose characteristic is at distance $L$ from a domestic product. Hence, $t_{p}$ eliminates international trade.

Secondly, consider the equilibrium in which the domestic producers do not fear foreign competition. Using (4), the demand faced by any firm $i$, knowing that 2L separates any two adjacent products, is

$$
Q D_{i}=\frac{D}{2}\left(p_{i+1}+p_{i-1}-2 p_{i}+4 L\right) \text {. }
$$

Maximizing the gross profit of firm $i\left(R_{i}=\left(p_{i}-c\right) Q D_{i}\right)$, the equilibrium price in the symmetric equilibrium is equal to $p_{a}=p_{i}=p_{i+1}=p_{i-1}=2 L+c$. Observe that $p_{e}=p_{a}$ when $t=t_{p}(\operatorname{see}(9))$. Hence, at $t=t_{p}$, not only trade is eliminated but also the foreign competition has no influence on the behaviour of the domestic firms.

Thirdly, since by definition $L$ is the longest distance between foreign and domestic products in the interleaved arrangement, $t_{p}$ prevents trade as well as the foreign competition from affecting the domestic firms whatever the set of characteristics of the foreign products. I

The intuitive explanation for $t_{p}$ is the following. When the products become more differentiated ( $L$ gets larger), the market share of the foreign products increases for any given tariff rate, and thus so does the prohibitive tariff rate. Conversely, a higher marginal cost increases the import price relative to the domestic price for any given positive tariff rate which implies a lower prohibitive tariff rate.

Assuming $t=t_{p}$ in (9) to (14), the no-trade zero-profit equilibrium is characterized by

$$
\begin{aligned}
& P_{a}=2 \underline{L}+c, \\
& Q_{a}=2 D \underline{L},
\end{aligned}
$$


(16) $L(t=t)=\frac{1}{2} \underset{P}{\left(\frac{K}{D}\right)^{3 / 2}}$,

and the equilibrium number of domestic products is

(16)' $n(t=\underset{p}{t})=\underset{k}{(-)})^{2 / 2}$

In free trade, any market configuration is possible. For convenience, however, the interleaved market arrangement is maintained. The free-trade equilibrium is found by assuming that $t=0$ in (9) to (14). The free-trade zero-profit equilibrium is characterized by

$$
\begin{aligned}
& p_{e}=q_{e}=\underline{L}+c, \\
& \Sigma Q=2 D \underline{L},
\end{aligned}
$$

(17) $\underline{L}(t=0)=\left(\frac{K}{2 D}\right)^{1 / 2}$,

and the equilibrium number of domestic brands is

(17)' $n(t=0)=\left(\frac{D}{2 K}\right)^{1 / 2}$

Comparing these two equilibria is now straightforward.

Proposition 3. With totally inelastic consumer's demand, a complete market integration from an autarkic equilibrium between two identical countries leads to (i) a decrease in the number of domestic firms, (ii) an increase in the scale of production of each remaining product, (iii) an increase in the product diversity and (iv) an increase in price competition.

Proof. These conclusions follow from the comparison of (15) and (17) or 
(15)' and (17)': (i) holds since $n\left(t=t_{p}\right)>n(t=0)$; (ii) follows from the fact that total sales are equal to $2 D \underline{L}$ and $\underline{L}(t=0)>\underline{L}\left(t_{p}\right)$; (iii) holds since $2 n(t=0)>n\left(t=t_{p}\right)$ and (iv) prices decrease because they depend positively on the distance between brands and $2 \underline{L}\left(t=t_{p}\right)>\underline{L}(t=0)$. $\|$

These results can be considered as the basic market structure effects of trade liberalization in differentiated product industries. They can be found in Dixit and Norman (1980), Krugman (1979) and Lancaster (1980) among others. In the present model, however, the no-trade equilibrium is endogenously determined.

\section{Comparative statics}

The specification of the model makes it possible to analyse the impact of a change in the tariff rate on market structure. Consider the effects of tariff changes assuming first that the number of products is fixed ( $L$ is given). Totally differentiating the gross profit function of the representative firm $(R=R D(p(t, L), q(t, L), t, L)+R F(p(t, L), q(t, L), t, L))$ and simplifying (i.e., the first-order conditions $\mathrm{RD}_{p}=R F_{q}=0$ ), it reduces to

$$
\left.\frac{d R}{d t}\right|_{L}=R D_{t}+\left.R D_{q} \frac{d q}{d t}\right|_{L}+R F_{t}+\left.R F p \frac{d p}{d t}\right|_{L}
$$

where suscripts indicate the variables of partial derivatives. A reciprocal tariff reduction has two effects. The first one is the direct effect of the tariff change on gross profits. The tariff reduction induces some consumers to switch from domestic to imported brands $\left(R D_{t}>0, R F_{t} \leq 0\right)$. Even if firms sell in both markets and therefore benefit from tariff reductions on foreign sales, this direct effect tends to decrease gross profits since, when $t>0$, the markup on domestic sales is higher than on foreign sales. 
The second effect is due to the price adjustment of the firms. Totally differentiating the first-order conditions (7) and (8), substituting them into each other and rearranging, one can isolate the effect of a change in tariff on prices:

$$
\frac{d p}{d t \mid L}=\frac{R D_{p q} R t^{R D}-R F q_{p t}^{R F}-R p_{p q} R F}{q p}=\frac{c}{3}>0
$$

(19)

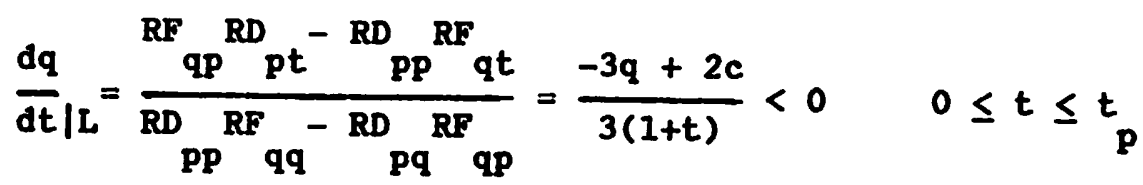

A tariff reduction induces firms to decrease their domestic price by a constant term and to increase their net foreign price. This increase is greater, the lower is the tariff rate. Since $\mathrm{RD}_{\mathrm{q}}>0$ and $\mathrm{RF} p \geq 0$, the price adjustment of its direct competitors is beneficial to the domestic gross profit of the representative firm $\left(R D_{q}(d q / d t \mid L)<0\right)$ and detrimental to its foreign gross profit $\left(R F_{p}(d p / d t \mid L) \geq 0\right)$. Hence, $d R / d t \mid L$ can be positive or negative.

Lemma 1. With ad valorem tariff rate, inelastic consumer's demands and a fixed number of products, there exists a reciprocal tariff rate $t_{0}$ such that $0<t_{0}<t_{p}$, which minimizes the gross profit of the representative firm.

Proof. The tariff rate $t_{0}$ is such that $d R / d t / L=0$. Using (13), $t_{0}$ satisfies

$$
t^{3}+t^{2}\left(\frac{5}{2}+\underset{c}{3-}\right)+2 t\left(1+3 \frac{L}{c}\right)-\frac{9 L^{2}}{2 c^{2}}=0
$$

Since $d^{2} R / d t^{2} \mid L>0, t_{0}$ minimizes the gross profit of the representative firm. In addition, $t_{0}$ is strictly positive but less than $t_{p}$ since $d R / d t / L$ 
is strictly negative at $t=0$ and strictly positive at $t_{p} \cdot \|$

Figure 2

Figure 2 illustrates the effect of the tariff on the gross profit of the representative firm. The total gross profit (R) is U-shaped with respect to $t$. The gross profit on domestic sales (RD) is an increasing function of $t$ converging to the no-trade gross profit, whereas the gross profit on foreign sales (RF) is decreasing, converging asymptotically to zero at the prohibitive rate.

Hence, for a given number of products, tariff reductions may increase firm's profit. The intuitive explanation of this result is simple. At positive tariff rates, the price elasticity of the foreign demand is higher than that of the domestic demand. Reciprocal ad valorem tariff reductions not only bring the elasticities together but they also decrease the foreign demand elasticity more than they increase the domestic one. As a result, the absolute change in the foreign markup is greater than the change in the domestic markup. As long as the share of domestic sales is large with respect to foreign sales, the gains on the foreign market cannot compensate for the losses on the domestic market. However, when market shares are not too far apart, the foreign market effect dominates the domestic effect, and thus the total gross profit of the representative firm increases with tariff reductions. This effect occurs provided $t_{0}$ is relatively low.

When the zero-profit condition is taken into account, a change in the tariff rate affects the number of products. The zero-profit condition is satisfied when the effects of a tariff change on the gross profit are compensated by the exit or the entry of firms, and thus by the change in the distance between products.

It is straightforward to show that entry occurs when reciprocal tariff reductions increase firm profits, and that exit must take place when profits 
decrease.

Denoting by $d R / d L / t$ the effects on the gross profit of the change in the distance between products at given tariff rates, the zero-profit condition implies that

$$
\frac{d L}{d t}=-\frac{d R / d t / L}{d R / d L / t} .
$$

The denominator of $(20)$ is

$$
\frac{d R}{d L / t}=R D_{L}+R F+R D_{q} \frac{d q}{d L / t}+R F \frac{d p}{p L / t}
$$

Since the four terms of this expression are unambiguously positive (see (9), (10) and (13)), dL/dt and $\mathrm{dR} / \mathrm{dt} / \mathrm{L}$ have opposite signs, implying that entry (exit) takes place when $\mathrm{dR} / \mathrm{dt} / \mathrm{L}>0(<0)$.

These results have important implications on the market-structure effects of trade liberalization in differentiated product industries. The following proposition summarizes them.

Proposition 4. With inelastic consumer's demand, small reciprocal tariff reductions lead to increases or decreases in the number of domestic firms (or products) in both countries and in the total volume of production of every product, depending upon the initial value of the ad valorem tariff rate. In particular, if the initial tariff rate is smaller than $t_{0}$, a small reciprocal tariff reduction increases the number of firms and decreases the total volume of production. Price competition, however, always increases with reciprocal trade liberalization.

Proof. Since $\mathrm{dL} / \mathrm{dt}$ and $\mathrm{dR} / \mathrm{d} t / \mathrm{L}$ have opposite signs and $\mathrm{L}$ is inversely related to $n, d n / d t$ has the same sign as $d R / d t / L$. Since $d R / d t / L<0$ for $0 \leq t<t$ o and $d R / d t \mid L>0$ for $t_{0}<t \leq t_{p}$, small tariff reductions lead to 
entry when the initial tariff rate is below $t_{0}$ and to exit when it is above. Moreover, $\mathrm{d} Q / \mathrm{dt}=2 \mathrm{DdL} / \mathrm{dt}$ since $\mathrm{firm}$ 's total production is equal to $Q=$ 2DL regardless of the tariff rate. Hence the total production of the representative firm increases (decreases) when tariff cuts lead to exit (entry).

Price competition, however, always increases with trade liberalization in a zero-profit equilibrium, since

$$
\begin{gathered}
\frac{d q(1+t)}{d t}=\frac{d q(1+t)}{d t}\left|L+\frac{d q(1+t)}{d L}\right| t \frac{d L}{d t}=\frac{2 c(p-c)+3\left(q-c^{2}\right)}{6((p-c)+(q-c)}>0, \\
\frac{d p}{d t}=\frac{d p}{d t \mid L}+\frac{d p}{d L \mid t} \frac{d L}{d t}=\frac{(3 q+c)(q-c)}{6((p-c)+(q-c))} \geq 0 . \|
\end{gathered}
$$

Figure 3 illustrates the relationship between the number of domestic firms (or products) and the tariff in the zero-profit equilibrium. Using (13) and (14), the market equilibrium distance between adjacent products is found by solving for the positive roots of the polynomial. The market equilibrium number of brands $(n)$ is found knowing that $n=1 /(2 L)$.

Figure 3

These results are interesting; they imply that the effects of trade liberalization on market structure of differentiated product industries depend on both the initial level of the ad valorem tariff rate and on the extent of the tariff reduction. Even if both countries are identical and tariff feductions are reciprocal, the number of domestic products does not decrease continuously from no trade to free trade. Hence, results based on the comparison between these two limiting equilibria cannot be used to predict the effects of intermediate tariff reductions.

Horeover, the net entry of firms has detrimental effects on average cost since the total production of firms may decrease. Exploitation of economies 
of scale may thus lessen with reciprocal trade liberalization. This is not inconsistent with increased price competition even in a zero-profit equilibrium, since producers set two prices and their net foreign price increases with tariff reductions.

Elastic Individual Demand

In this section, the assumption of the inelasticity of individual demand is relaxed. The influence on market structure is considered by analysing whether elastic demand and tariff reductions facilitate entry or make entry more difficult as compared with the inelastic case.

A totally price inelastic individual demand implies that, for a given distance between adjacent domestic products, the total volume sold by a firm is independent of the tariff rate. Since prices depend on distance between adjacent products (not necessarily domestic), the no-trade equilibrium price is higher than the interleaved free-trade equilibrium price. Thus, for a given distance between adjacent domestic products, firms always prefer no trade to free trade. This is sufficient to explain why, in a zero-profit equilibrium, complete market integration must result in the exit of domestic firms.

If the consumer's demand is price elastic, demand is inversely related to the distance between the consumer's most preferred characteristic and the characteristic of available products. Given prices and the distance between adjacent domestic products, the total volume sold by any firm must now be larger in free trade than without trade, because, in free trade, the consumer's most preferred characteristic is, on average, closer to the available products. The higher the consumer's demand elasticity, the larger is this quantity effect. Hence, provided that the consumer's demand is sufficiently elastic, reciprocal tariff reductions may increase the 
representative firm's gross profit not only from low initial tariff rates but with respect to the no-trade equilibrium as well (dR/dt $\mid \mathrm{L}<0$ for $0 \leq t \leq$ tp). (Appendix B explicitly shows this possibility). Freer trade leads, in this case, to more domestic firms as compared with the no-trade equilibrium. Hence elastic demand and tariff reductions facilitate entry as compared with the inelastic case.

The elasticity of individual demand, the initial tariff rate and the extent of bilateral tariff reductions are therefore important in determining the market structure effects of bilateral tariff reductions.

\section{Optimality}

In a closed economy, consumers are on average better off when products are closer in the characteristic space. An increase in product diversity, however, implies a smaller scale of production in the presence of economies of scale. There is therefore a trade off between product diversity and scale of production, implying the existence of an optimal mix that maximizes welfare (Dixit and stiglitz (1977), Salop (1979)). This section investigates the consequences of trade liberalization on this optimal mix and on the welfare of each country.

To keep the analysis as simple as possible, it is assumed that individual demand is perfectly price inelastic. Trade is shown to be always better than no trade, but the market equilibrium is not socially optimal, and free trade does not by itself constitute the best feasible solution for the trading countries.

The welfare function for one country is represented by the sum of the consumer and the producer surpluses. Optimality requires that products be symmetrically spaced throughout the characteristic space and that consumers buy the cheapest available product. If the tariff rate is non-prohibitive, 
the marginal consumer is at a distance $x_{i}^{*}-\bar{x}=x$ from a domestic product (and thus at a distance $(L-\bar{x})$ from an imported product). From (2), the consumer's reservation price is $\left(I-\left|x_{i}-x^{*}\right|\right)$, so that the gross surplus of one unit of a product (domestic or imported) is $\left(I-\left|x_{i}-x^{*}\right|-c\right)$. The total surplus over a representative segment (2L) of the characteristic space of one country is

(21) $W^{\prime}=2 D \int_{0}^{\bar{x}}(I-x-c) d x+2 D \int_{0}^{L-\bar{x}}(I-x-q(1+t)) d x+(q-c) Q F+t q Q F-X$

where $x=\left|x_{i}-x^{\star}\right|$. The first term represents the gross surplus associated with consuming a domestic product and the second term is the net consumer's surplus of consuming an imported product. The three last terms are respectively the gross profit on exports, the tariff revenue and the domestic resource cost. Integrating, the average total surplus per unit of characteristic space $(W=W / 2 L)$ is

$$
W=D\left(I-c-\frac{L}{4}-\frac{(q(1+t)-p)^{2}}{4 L}\right)-\frac{K}{2 L}
$$

The interpretation of (22) is the following. In free trade, all the prices are equal and thus the marginal consumer incurs a disutility equal to $\mathrm{L} / 2$ when L separates products. Since the consumers are uniformly distributed, the average disutility is $\mathrm{L} / 4$. Away from free trade, the average consumer's disutility also depends on the price difference between adjacent products. The average net surplus per consumer is then $(I-c-L / 4-(q(1+t)$ $\left.-p)^{2} / 4 L\right)$.

Proposition 5. For both countries, trade is better than no trade but there exists a positive tariff rate $t *$ which maximizes welfare associated with the market equilibrium. 
Proof. The welfare function is maximized with respect to $t$ subject to the constraint that the zero-profit condition always holds. Hence,

(23) $\operatorname{Max} 2^{*}=W+u_{1}(L-L)$

with $u_{1}>0$ and $(\underline{L}-L)$ corresponding to the zero-profit equilibrium constraint $(K-R(D, L, C, t) \geq 0)$. Since $t_{0}$ corresponds to the tariff bringing the maximum distance between pairs of adjacent products in the market equilibrium $(\partial(\underline{L}-L) / \partial t=0), \partial(\underline{L}-L) / \partial t$ is positive for $0 \leq t<t_{0}$ and negative for $t_{0}<t \leq t_{p}$. In addition, since $\partial w / \partial t \leq 0$ for $t \geq 0$, then $\partial Z * / \partial t=\partial W / \partial t+u_{1} \partial(\underline{L}-L) / \partial t$ must be negative for $t_{0} \leq t \leq t_{p}$, but can be positive or negative for $0 \leq t<t_{0}$. In other words, small tariff reductions unambiguously increase welfare when these reductions occur between $t_{p}$ and $t_{0}$, but may deteriorate welfare when $t$ falls from $t_{0}$. Tariff cuts unambiguously decrease welfare in the neighbourhood of free trade since $\partial z * / \partial t>0$ for $t \sim 0$ (see Appendix $C$ ).

There exists, therefore, a positive tariff rate $t *$ for which $\partial z * / \partial t=$ 0 . Substituting (15) and (17) into (22), it is easy to verify that $w(t=0)>$ $w\left(t_{p}\right)$, so that welfare never decreases enough to reach its no-trade level. 6 Hence, $w(t)>w\left(t_{p}\right)$ for $0 \leq t<t_{p}$ or trade is better than no trade.ll

In other words, welfare increases with reciprocal tariff reductions, reaches a maximum at some positive tariff rate $t *$ (such that $0<t^{*}<t_{0}$ ) and decreases as the tariff rate approaches zero.

The immediate corollary of this proposition is that reciprocal tariff reductions may decrease welfare in both countries, depending on the initial tariff rate and on the extent of the tariff cut. In particular, welfare unambiguously decreases when the tariff is reduced from t*. 
The existence of a positive tariff rate maximizing welfare usually suggests that the tariff is offsetting existing distortions. In this model, there are two closely related distortions: the market imperfection due to economies of scale and the excess product diversity brought by the market equilibrium.

Maximizing (23) with respect to L, it can be shown (see Appendix C) that only $u_{1}>0$ is feasible, so that the constraint $\underline{L}-L \geq 0$ is binding. Given this constraint, the socially optimal distance between products is longer than L. since $\partial W / \partial L>0$ for any tariff rate such that $0 \leq t \leq t_{p}$. Moreover, this result holds for any positive and finite consumer's density $D$ (or size of the economy). In contrast to Horn's (1984) results, there is no optimal size of the economy in this characteristic space model.

Excessive product diversity is thus a strong feature of this model. This is consistent with most one-dimensional space models (see for instance Salop (1979), Eaton and Wooders (1985)).

It is now easy to explain the particular value of the welfare maximizing tariff rate $t^{*}$. Two opposite forces determine its exact value. First, since the market forces lead to too many products, welfare tends to be maximized when the excessive product diversity is minimized $(\partial(\underline{L}-\mathrm{L}) / \partial t=0)$. This rate also corresponds to the maximum firm production, since $Q=2 D L$, and thus $t_{0}$ minimizes (but does not eliminate) the distortion due to economies of scale. Secondly, for a given number of products (or distance between products), welfare is maximized in free trade, since the consumer's average cost of deviation from most preferred product depends upon the price distortion of adjacent products, and this distortion is minimized in free trade (see (22)). It is then not surprising that the tariff rate that maximizes welfare in the market equilibrium lies between the rate giving the minimum number of 
products $\left(t_{0}\right)$ and zero.

It is important to consider the robustness of this result and in particular to analyse whether commercial policy is the most efficient tool to bring the economies to a welfare maximizing market equilibrium.

Commercial policy is unable to produce a first-best optimum equilibrium because there is no tariff rate that produces the optimal number of products, and even if such a tariff rate existed, imperfect competition would subsist. Given this second-best situation, an efficient tool must reduce the number of products without distorting the consumer's prices. A production tax is the natural choice in this context. It increases the marginal cost of production reducing the incentive to introduce new products and thus it deals directly with the distortions. It may, however, distort consumer prices depending on who is implementing the tax.

The problem is the following. In characteristic space models, a tax affects consumer prices since each firm detains some monopolistic power. For a given number of products, however, total welfare is unaffected by uniform price changes because, with inelastic consumer's demand, total surplus remains constant as long as the consumer's income is not binding. Welfare is reduced only when the tax distorts the relative price of domestic versus imported products inducing marginal consumers to switch their allocation from one product to another thereby increasing the consumer's average cost of deviation from most preferred product. This suggests that a production tax is more efficient than tariff when the former avoids to distort import versus domestic prices.

Proposition 6. If the same production tax rate is used by the two identical 
countries to optimize the number of domestic products, then the free trade market equilibrium maximizes welfare in both countries.

Proof. Define $\rho\left(\rho^{*}\right)$ as the production tax rate levied by the domestic (foreign) country on production prices. The total surplus over $2 \mathrm{~L}$ of the market is

$$
W^{\prime}=2 D \int_{0}^{\bar{x}}(I-c-x) d x+2 D \int_{0}^{L-\bar{x}}(I-x-T q F) d x+\left(q^{*} F^{*}-c\right) Q F^{*}+(t q F) Q F-K
$$

where $F=1+p, T=1+t$ and $*^{\prime} s$ indicates values in the foreign market. Integrating (24) and considering the effect of a change in tariff on the average total surplus per consumer $\left(W=W^{1} / 2 D L\right)$ :

$$
\begin{aligned}
\frac{\partial W}{\partial t}= & \frac{c}{6 L}\left(c\left(F^{*}-F\right)+\frac{c}{3} F\left(F^{*}-F T\right)+\left(F^{2} q-F^{*} q^{*}\right)\right) \\
& +\frac{F^{*}}{2 L}\left(L+\frac{c}{3}\left(F-F^{*} T\right)\right) \frac{\partial q^{*}}{\partial t}-\frac{F}{2 L}\left(L+\frac{c}{3}\left(F^{*}-F T\right)\right) \frac{\partial q}{\partial t}
\end{aligned}
$$

When $\left.p=p^{*}, \partial W / \partial t=-\left(c^{2} / 18 \mathrm{~L}\right)\right)^{2} t$. Hence a maximum exists at $t=0$. In this case, the average welfare surplus per consumer is equal to I - c $-L^{2} / 4-$ $\mathrm{K} / 2 \mathrm{DL}$ and the optimal number of domestic products to $n=(\mathrm{D} / 8 \mathrm{~K})^{4 / 2}$. This social number of domestic products can be reached by appropriate choice of $\rho=\rho^{*}$ since the representative firm's profit in the presence of production tax is equal to

(26) $\Pi=\frac{D}{F}\left(L+\frac{C}{3}\left(T \cdot F^{*}-F\right)\right)^{2}+\frac{D}{T \cdot F}\left(L-\frac{C}{3}\left(T \cdot F-F^{*}\right)\right)^{2}-K$,

8o that, in free trade and with $\rho=\rho^{\star}$, the zero-profit equilibrium number of domestic product corresponds to $(D / 2 F K)^{3 / 2} \cdot \|$

This proposition is not surprising given the theory of domestic distortion. It implies, however, that both countries must intervene conjointly. In addition, welfare reaches a higher level than with tariff 
policy alone. This is the case since consumer's average cost of deviation from most preferred product is minimized in free trade and the optimal number of products is reached. Hence the superiority of complete trade liberalization is re-established, provided the two identical countries also agree on a coninon production tax to obtain the first-best number of products.

\section{Conclusion}

This paper has investigated the market structure and the welfare effects of reciprocal trade liberalization between two identical countries. The three main points of this paper can be summarized as follows. First, in a one-dimensional characteristic space approach, the basic market structure effects of a complete market integration between two identical countries can be obtained with a model in which the prohibitive tariff rate is endogenously determined. This result has been shown by demonstrating that the equilibrium configuration of the products must be interleaved. Secondly, the market structure results based on the comparison of the no-trade and the free-trade equilibrium cannot be generalized to all intermediate, small reciprocal tariff

reductions. With ad valorem tariff rate and reciprocal tariff reductions, the equilibrium number of domestic firms (products) can increase or decrease depending on both the initial tariff rate, the extent of the tariff cut and the elasticity of the consumer's demand. In addition, when consumer's demand is price inelastic, the total production of every firm depends only on the firm market size. Exploitation of economies of scale can thus improve or deteriorate depending on whether domestic firms exit or enter the market. Price competition, however, always increases. These market structure results suggest that when, in a differentiated product industry, the inital tariff 
rate and the response to price changes are both low, freer trade increases the number of domestically produced goods and deteriorates the exploitation of firm economies of scale.

Thirdly, the model also shows that the market equilibrium brings too much product variety. This result is consistent with most existing models using the one-dimensional space approach. As Spence (1976) and Salop (1979) have shown, the optimal number of products depends on the difference between the average and the marginal consumer's surplus relative to the cost of introducing a new product whereas the market equilibrium number of products depends on the profitability condition. Even if this result is not general and depends upon the specification of the model, there is no reason to expect that imperfect markets should necessarily bring the social optimal number of products. When product diversity is excessive, this model shows that there exist positive ad valorem tariff rates which bring higher welfare level than free trade. Excessive product diversity is not sufficient for this result to occur. The barrier to trade must also distort the market equilibrium such that when it marginally increases from free trade, it induces larger gains in efficiency than it adversely affects the average consumer cost of deviation from most preferred product. The ad valorem tariff has this property that other barriers to trade may not have. The superiority of free trade however is reestablished if both countries can agree on production tax aiming at eliminating excess product diversity as they liberalize trade.

Even though these results are based on a specific model, it shows that comparing no-trade and free-trade can be misleading on both the market structure and the welfare effects of reciprocal tariff reductions. 


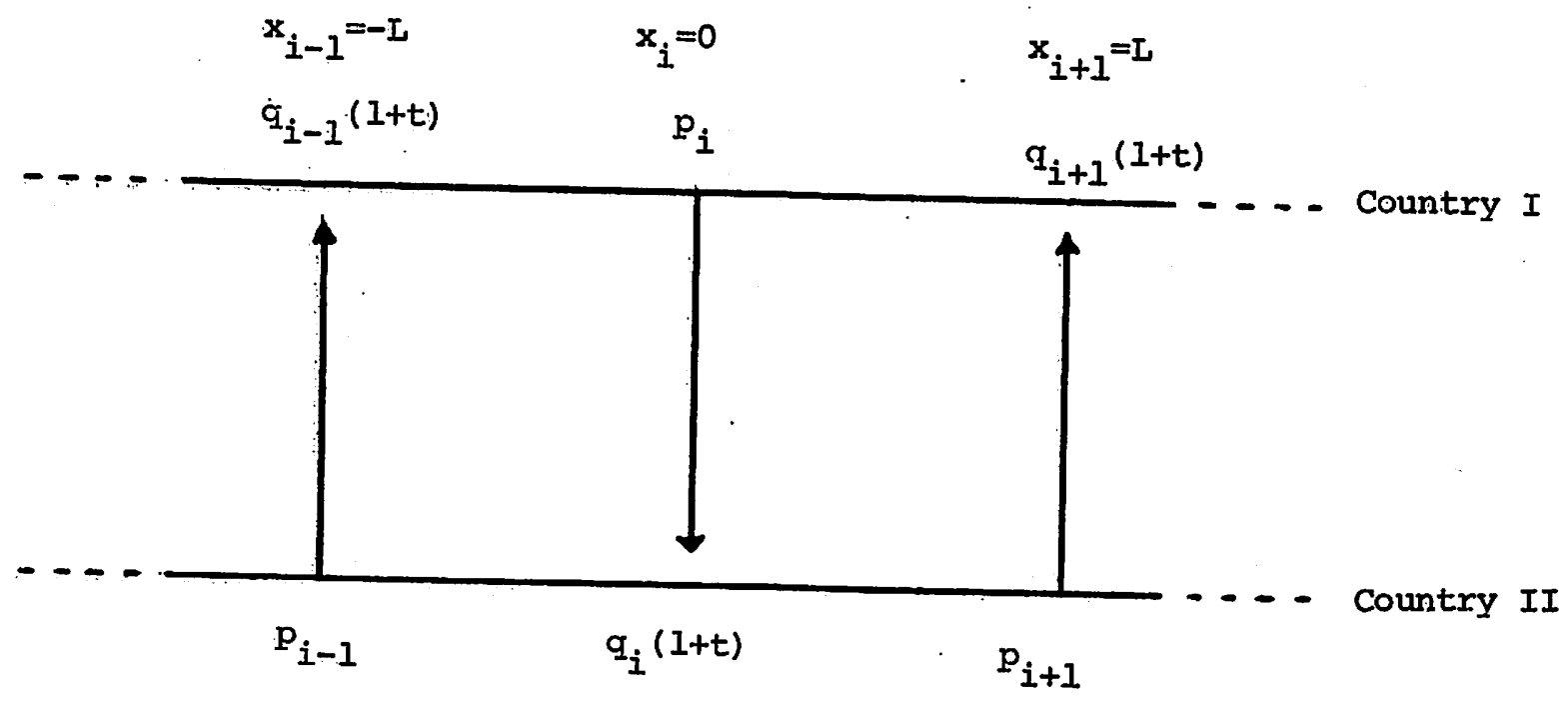

Figure 1 


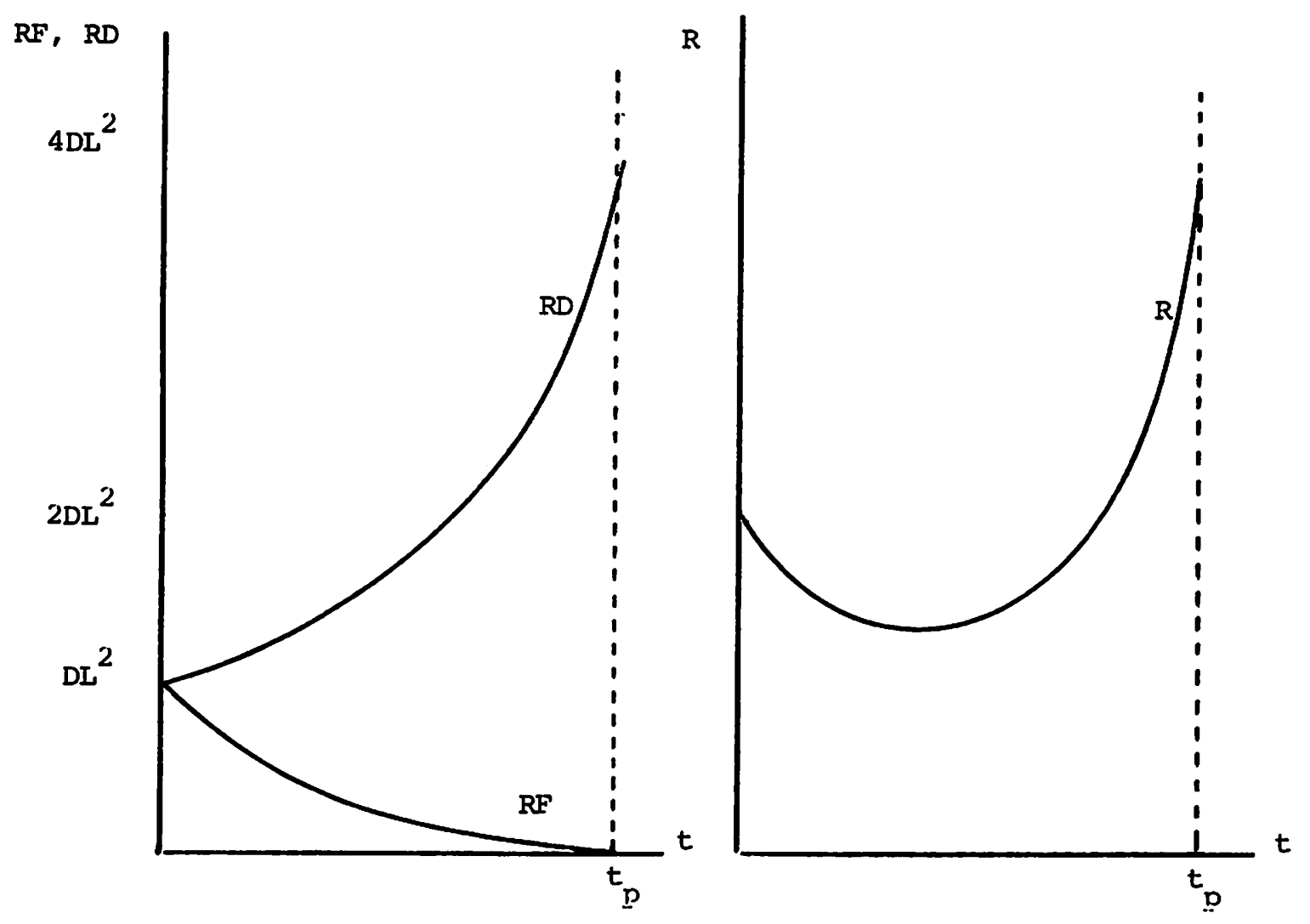

Figure 2 


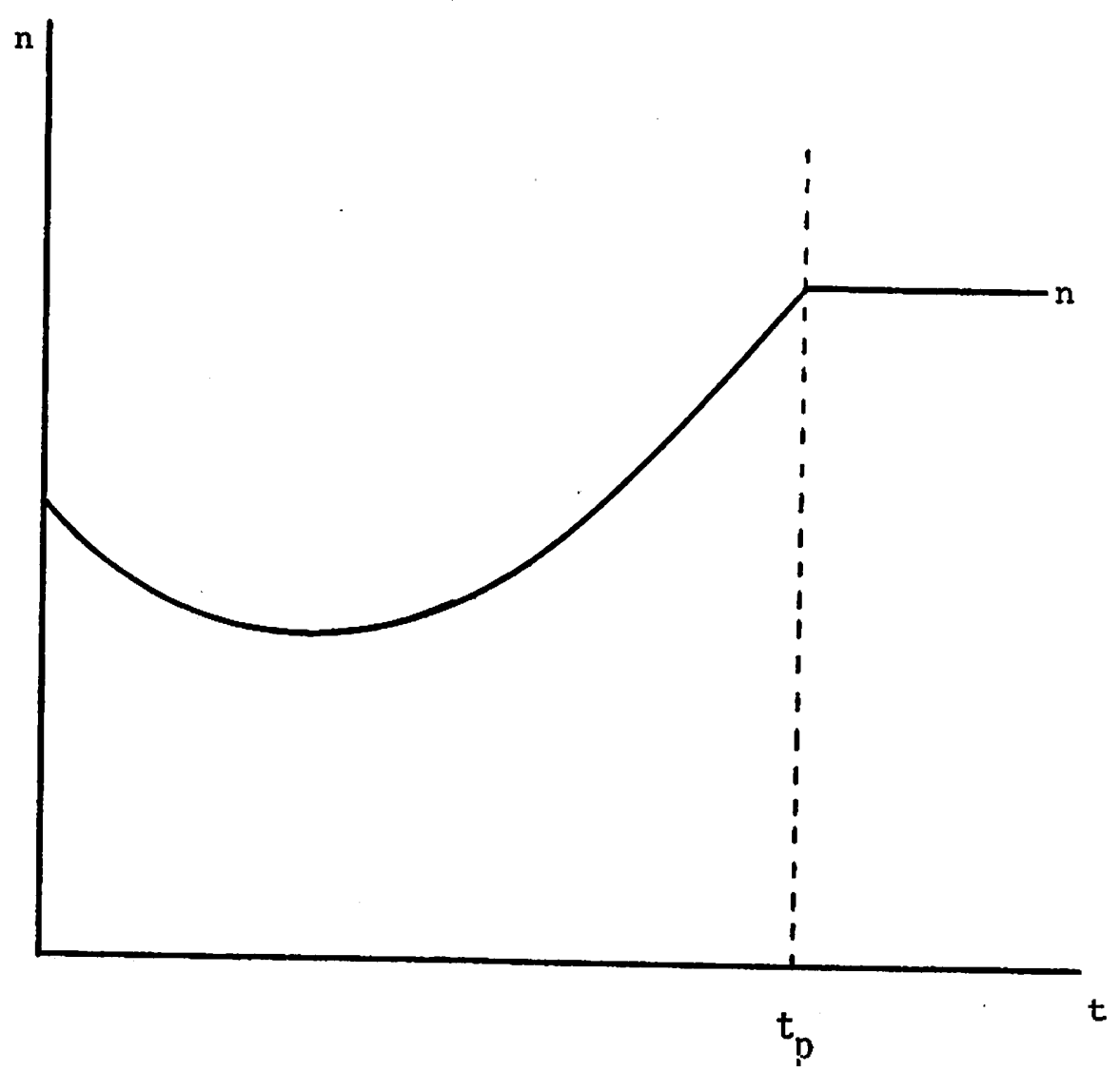

Figure 3 


\section{Appendix A}

There are three symmetric configurations: (i) the interleaved arrangement, (ii) the matching arrangement (the same set of products is produced in each country) and (iii) the split arrangement (each country produces all the products in separate half of the characteristic space). A product configuration is an equilibrium if, for any tariff rate consistent with the arrangement, it does not pay any firm $i$ to change its characteristic and price given the characteristic and price of the other firms (subject to no price undercutting). We show that only the interleaved arrangement has this property.

\section{Interleaved arrangement}

The interleaved arrangement is described by (9) to (13). Suppose firm i relocates the characteristic of its product anywhere in between a domestic and an imported product (see Figure 1). In this case, the domestic and the foreign demands are respectively,

(A.1) $Q D_{i}=\frac{D}{2}\left(P_{i+1}+T q_{i-1}-2 p_{i}+L\right)$ and $Q F_{i}=\frac{D}{2}\left(T q_{i+1}+p_{i-1}-2 T q_{i}+L\right)$ where $T=(1+t)$ and $P^{\prime} s$ and $\left(q^{\prime} s\right)$ represent domestic (net foreign) prices. Maximizing firm $i$ gross profit and solving the first-order conditions, the firm i equilibrium prices, assuming that other prices remain constant, are $p_{i}=3 L / 4+c+t c / 4$ and $q_{i} T=3 L / 4+c+3 t c / 4$. Substituting these prices as well as $p_{e}=p_{i+1}=p_{i-1}$ and $q_{e}=q_{i+1}=q_{i-1}$ as given by (9) and (10) into (A.1), firm i new gross profit is (A.2) $\tilde{R}_{1}=\frac{D}{16}\left((3 L+t C)^{2}+\frac{1}{T}(3 L-t C)^{2}\right)$

For $0 \leq t \leq t_{p}, \tilde{R}_{i}<R_{i}$ as given by (13). Hence, the interleaved arrangement constitutes an equilibrium since there is no tariff rate 
consistent with this configuration at which it pays firm $i$ to change the characteristic of its product.

\section{Matching arrangement}

In the matching arrangement, the direct competition between firms located in different countries results in a Bertrand equilibrium when the tariff rate is not high enough to isolate the countries. In this case, the Bertrand equilibrium price is $\mathrm{CT}$ and the gross profit is DLct.

Assume there exists a zero-profit equilibrium in which $t, L$ and $F$ are strictly positive and that firm i moves closer to firm (i+1) at whatever characteristic setting optimal prices for the domestic and foreign markets. The other firms do not change price or characteristic including the foreign direct competitor of firm $i$ in the matching arrangement which is assumed to capture a share of the domestic market at its original price. The domestic and foreign demands for brand $i$ at its new characteristic are, respectively, (A.3) $Q D_{i}=\frac{D}{2}\left(p_{i+1}-2 p_{i}+q_{i-1} T+L\right)$ and $\left.Q F_{i}=\frac{D}{2}{ }_{i+1}^{-2 p_{i}} T+p_{i-1}+L\right)$

Haximizing firm $i$ gross profit with respect to $p_{i}$ and $q_{i}$ gives respectively $p_{i+1}-4 p_{i}+q_{i-1} T+L+2 c=0$ and $p_{i+1}-4 q_{i} T+p_{i-1}+L+2 c T=0$. Setting $p_{i+1}=q_{i-1} T=p_{i-1}=c T$, then $p_{i}=L / 4+c+c t / 2$ and $q_{i} T=L / 4+c T$. Substituting the prices into the relevant functions, firm $i$ gross profit becomes

(A.4) $\tilde{R}_{i}=\frac{D L}{4}\left(\frac{D}{2}+C t\right)^{2}+\frac{D L}{T} \frac{(-)^{2}}{4}$

It exists values of the parameters (for instance, $D=t=c=1, L=10$ ) for which $\tilde{R}_{i}>R_{i}=$ DLct. Therefore, the matching arrangement cannot be an equilibrium. 


\section{Split arrangement}

With $L$ separating any two adjacent brands, the domestic and foreign demands for product $i$ in the split arrangement are respectively (disregarding products at boundaries)

(A.5) $Q D_{i}=\frac{D}{2}\left(P_{i+1}-2 p_{i}+p_{i-1}+2 L\right)$ and $Q F=\frac{D}{2}\left(T q_{i+1}-2 q_{i} T+T q_{1-1}+2 L\right)$

Maximizing firm $i$ gross profit with respect to $p_{i}$ and $q_{i}$ and assuming that firms are identical, the equilibrium prices are $p_{i}=p_{i+1}=p_{i-1}=L+c$ and $q_{i} T=q_{i-1} T=q_{i+1} T=L+c T$. Substituting these prices into (A.5), $Q D_{i}=Q F_{i}$ $=$ DL. Hence, firm i gross profit is

$(A .6) R_{i}=D L(\stackrel{2+t}{1+t})$

Assume now that firm i relocates its product half way in between two imported products in the other half of the characteristic space and exports in the foreign market. The demands become

(A.7) $Q D_{i}=\frac{D}{2}\left(T q_{i+1}+T q_{i-1}-2 p \underset{i}{+L)}\right.$ and $Q F \underset{i}{=}=\frac{D}{2} p_{i+1}^{+p_{i-1}}{ }_{i}^{\left.-2 T q_{i}+L\right)}$

Maximizing firm i gross profit with respect to prices and solving the relevant first-order conditions assuming that other firms keep their price constant, $p_{i}=q_{i} T=3 L / 4+c+c t / 2$. After substitution, firm $i$ gross profit at

its new location is

(A.8) $\tilde{R}_{i}=\frac{D}{4}\left(\left(\frac{3}{2} L+c t\right)^{2}+\frac{1}{T}\left(\frac{3}{2} L-c t\right)^{2}\right)$

The second term of (A.8) represents the gross profit of firm $i$ in its foreign market. It reaches zero when $t=3 \mathrm{~L} / 2 c$. At this tariff rate, the revenue on domestic sales is equal to $\tilde{R}_{i}=9 D L / 4>R_{i}$. Hence, the split arrangement is not an equilibrium. 


\section{APPEADIX B}

Assume that the individual demand is represented by

$$
v_{i}=\frac{\left(s_{i}+\left|x_{i}-x^{*}\right|\right)}{b}+1
$$

where $b$ is the slope of the demand, $v_{i}$ is the quantity demanded, and $s_{1}$ the mill price (equal to $p_{i}$ or $q_{i}(1+t)$ ). When $b=-\infty$, the individual demand becomes the inelastic demand assumed in the text. Assuming $D=1$, the domestic and foreign demands of firm $i$ are, respectively,

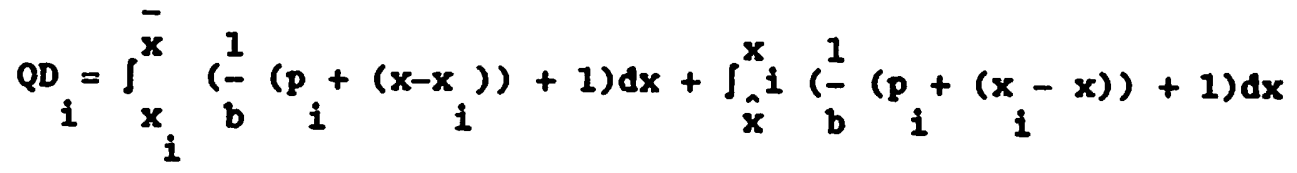

$$
\begin{aligned}
& \left.Q F=\int_{x}^{\bar{x}} \frac{1}{(-}\left(q_{i}(1+t)+\left(x-x_{i}\right)\right)+1\right) d x+\int_{\hat{x}}^{x} i{ }_{b}^{1}\left(q_{i}(1+t)+(x-x)+1\right) d x
\end{aligned}
$$

with $\bar{x}, \vec{x}$ as defined in the text. Haximizing the gross profit function of the firm $i(6)$, the first-order conditions in the symmetric interleaved case become

(A9) $\partial R_{i} / \partial p_{i}=(1 / 4 b)\left(-9 p_{i}^{2}+2 p_{i}(2 q T+2 L+3 c)+q^{2} T^{2}+2 L q T\right.$

$$
\left.+L^{2}-2 q T c-2 L c\right)+q T-2 p_{i}+L+c=0
$$

(A10) $\partial R_{i} / \partial q_{i}=(1 / 4 b)\left(-9 q_{i}^{2} T^{2}+2 q_{i} T(2 p+2 L+3 c T)+p^{2}+2 p L\right.$

$$
\left.+L^{2}-2 c T(p+L)\right)+p-2 q_{i} T+L+c T=0
$$


where $p(q)$ represents the domestic (foreign) price of the other (identical) products and $T=(1+t)$. The equilibrium demands faced by firm $i$ are

(AII) $\mathrm{QH}_{i}=(1 / 4 b)\left(-3 \mathrm{p}_{i}^{2}+2 \mathrm{p}_{i}(q \mathrm{qT}+\mathrm{L})+\mathrm{q}^{2} \mathrm{~T}^{2}+2 \mathrm{LqT}+\mathrm{L}^{2}\right)+q T-p_{i}+\mathrm{L}$ (A12) $Q F_{i}=(1 / 4 b)\left(-3 q_{i}^{2} T^{2}+2 q_{i} T(p+L)+p^{2}+L^{2}+2 p L\right)+p-q q_{i} T+L$

Using positive values for $c, t$, and $L$ 'and an iterative process to solve (A9) and (A10), one can show that there exists negative values of $b$ for which (i) $R(t=0) \geq R(t)$ for $0<t \leq t_{p}$, (ii) the second-order conditions are satisfied, namely that $R_{p p}<0, R_{q q}<0$ and $R_{p p} R_{q q}-R_{p q} R_{q p}>0$, and (iii) the entire market is covered. For instance, if $L=c=1$ and $b=-3.5$ :

\begin{tabular}{clllll}
$t$ & \multicolumn{1}{c}{$p^{*}$} & $Q D$ & $q^{*}(1+t)$ & $Q F$ & $R$ \\
0 & 1.677 & .449 & 1.677 & .449 & .608 \\
.6 & 1.771 & .526 & 2.085 & .2437 & .479 \\
1.2 & 1.83 & .591 & 2.476 & .0947 & .503 \\
1.862 & 1.862 & .649 & 2.862 & 0 & .561
\end{tabular}

Since the gross profit is the largest in free trade (and $d R / d L \mid t>0$ ), the free-trade zero-profit equilibrium has more domestic products than in any other equilibrium including the no-trade equilibrium.

\section{APPENDIX C}

\section{(i) Effect of a change in L}

Equation (23) is maximized with respect to $L$ knowing $W$ as given by (22) and ( $\underline{L}$ - L) by $\{-R(D, L, c, t)+K\}$ and (13). The first-order conditions are

(A.13) $\frac{\partial Z^{*}}{\partial L}=-\frac{D}{4}+\frac{D t^{2} c^{2}}{36 L^{2}}+\frac{K}{2 L^{2}}-\frac{2}{T}-D u_{1}\left((2+t) L+\frac{C t^{2}}{3}\right) \leq 0$ 
(A.14) $\frac{\partial z^{*}}{\partial u_{1}}=-D\left(L+\frac{t c^{2}}{3}\right)-\frac{D}{T}\left(L-\frac{t c^{2}}{3}\right)+K \geq 0$

(A.15) $u_{1} \frac{\partial z^{\star}}{\partial u_{1}}=0 ; L \frac{\partial z^{\star}}{\partial L}=0$

If $L>0$, there are two solutions for $u_{1}$ :

(1) $u_{1}=0$ or $L<\underline{L}$ : From (A.13), K/D $=\mathrm{L}^{2} / 2-\mathrm{t}^{2} \mathrm{c}^{2} / 18$. Substituting this into (A.14) gives $-9 L^{2}(3+t) / 2-t^{2} c^{2}(5+3 t) / 2-6 c L t^{2}>0$, which cannot be positive for positive values of $L, c$ and non-negative tariff rates. The constraint is thus binding.

(2) $\mathrm{u}_{1}>0$ or $\mathrm{L}=\overline{\mathrm{L}}$ : In this case, $\partial \mathrm{Z} * / \partial \mathrm{L}=0$ and $\partial Z * / \partial \mathrm{u}_{1}=0$. Using (A.13) and (A.14), $u_{1}$ is unambiguously positive. In addition, since $\partial(\underline{L}-L) / \partial L<0$ for any $t$, $\partial w / \partial L>0$ at $L=\underline{L}$.

(ii) Effect of a change in $t$

The welfare effect of a change in the tariff rate, given the zero-profit equilibrium, is found with

(A.16) $\frac{\partial z^{*}}{\partial t}=-\frac{t c^{2}}{18 L}+\frac{1}{T^{2}} u_{1}\left(L^{2}-\frac{2}{9} t^{3} c^{2}-\frac{t^{2} c}{3}\left(2 L+\frac{5}{3} c\right)-\frac{2 t c}{3}\left(2 L+\frac{2}{3} c\right)\right)$

The first term of (A.16) corresponds to $\partial w / \partial t$ and the second term to $\partial(L-L) / \partial t$. It is apparent that $\partial w / \partial t \leq 0$ for $t \geq 0$. since, in addition, $t_{0}$ is such that $\partial(\underline{L}-L) / \partial t=0$, then $\partial(\underline{L}-L) / \partial t \leq 0$ and thus $\partial Z * / \partial t<0$ for $t \geq t_{0}$. Since $\partial(\underline{L}-L) / \partial t>0$ for $t<t_{0}$, the sign of $\partial Z * / \partial t$ is ambiguous for $t<t_{0}$ but positive at $t=0$. Hence, $\partial z * / \partial t=0$ for $t *$ such that $0<t *<t_{0}$. 
NOTES:

Acknowledgements: Some of the results of this paper are contained in Chapter 2 of my doctoral dissertation for the University of Toronto. I am indebted to B. Curtis Eaton, Yehuda Kotowitz and Jim Helvin for helpful comments. All remaining errors are, of course, my responsibility. Financial supports from the Swiss National Science Foundation and from the Donner Project/International Economics Program at the University of Toronto are gratefully acknowledged.

Two preference structures are considered. Lancaster (followed by Helpman) obtains product diversity by assuming diversity of tastes. Product diversity can also be obtained by assuming consumer's preferences for variety (Dixit and stiglitz (1977)).

To our knowledge Lancaster (1984) is the only existing study introducing tariff in a characteristic space model. His analysis however has several shortcomings. First, Lancaster's results are derived from two product arrangements including one which cannot be an equilibrium given the assumptions of the model. Secondly, results are based on specific tariff rates and numerical examples but it is not known whether the results depend upon the choice of tariff rates. Finally, the welfare analysis is incomplete since it deals only with the consumer's side without reference to the cost of introducing new products.

3. This condition is obtained by observing first that the indirect utility function implied by the preferences defined in (1) is equal to

$\hat{u}\left(s_{i}, x_{i}, x^{*}\right)=I-s_{i}-\left|x_{i}-x^{*}\right|$ if $s_{i} \leq I-\left|x_{i}-x^{*}\right|$
and $\hat{u}\left(s_{i}, x_{i}, x^{*}\right)=0$ otherwise and secondly that $\hat{u}_{i}\left(s_{i}, x_{i}, x\right)=$ $\hat{u}\left(s_{i+1}, x_{i+1}, x\right)$ at $x$.

4. See Anderson (1986) for other ways to ensure the existence of the equilibrium.

The integer problem which may arise in a spatial model is disregarded since many firms are assumed to be involved in each market.

Although there is a discontinuity in the slope of the welfare function at the prohibitive rate, it can be verified that the level of welfare is the same whether the tariff increases from below (with (22)) or decreases from above. With no trade, the total surplus per unit of characteristic space is equal to $W=D(I-C-L a / 4)-K / L a$. since $L_{a}=2 L$ in equilibrium, the welfare level is exactly the same as predicted by (22) when $t=t_{p}$. 


\section{REFERENCES}

Anderson, S. (1986), Spatial Competition and Price Leadership, CORE Discussion Paper 8602, Universite Catholique de Louvain.

Archibald, G.C., Eaton B.C. and R.G. Lipsey (1986), "Address Models of Value Theory", in New Developments in the Analysis of Market Structure, J.E. Stiglitz and G.F. Kathewson (eds), MIT Press, Cambridge (Mass.).

Brander, J. and P. Krugman (1983), "A 'Reciprocal Dumping' Model of International Trade", Journal of International Economics.

Dixit, A.K. and J.E. Stiglitz (1977), "Monopolistic Competition and Optimum Product Diversity", American Economic Review, 67, 297-308.

Dixit, A.K. and V. Worman (1980), "Theory of International Trade", Cambridge University Press, Cambridge.

Eaton, B.C. and H. Wooders (1985), "Sophisticated Entry in an Address Model of Monopolistic Competition", Rand Journal of Economics,

Helpman, E. (1981), "International Trade in the Presence of Product Differentiation, Economies of Scale and Monopolistic Competition", Journal of International Economics, 11, 305-40.

Horn, H. (1984), Product Diversity, Trade and Welfare, in H. Kierzkowski, Monopolistic Competition and International Trade, Clarendon Press, Oxford, 51-68.

Hotelling, A. (1929), Stability in Competition, Economic Jouma1, 39, 41-57.

Krugman, P.R. (1979), "Increasing Returns, Monopolistic Competition and International Trade, Journal of International Economics, 9, 469-79.

Krugman, P.R. (1980), "Scale Economies, Product Differentiation and the Pattern of Trade", American Economic Review, 70, no 3, 950-59.

Krugman, H.R. (1981), "Intraindustry Specialization and the Gains from Trade", Journal of Political Economy, 89, no 5, 959-73.

Lancaster, K. (1984), "Protection and Product Differentiation" in H. Kierzkowski, Monopolistic Competition and International Trade, Clarendon Press, Oxford, 137-56.

Lancaster K. (1980), "Intra-Industry Trade under Perfect Monopolistic Competition", Journal of International Economics, 10, 151-75.

Lawrence C. and P.T. Spiller (1983), "Product Diversity, Economies of Scale, and International Trade", Quarterly Journal of Economics, 63-83.

Novshek W. (1980), "Equilibrium in Simple Spatial (or Differentiated Product) Models", Journal of Economic Theory, 22, 313-26. 
Salop S. (1979), "Konopolistic Competition with Outside Goods", Bell Journal of Economics, 10, 141-56.

Schmitt W. (1986), "Three Essays on Trade Liberalization in Differentiated Product Industries", Unpublished PhD Thesis, University of Toronto.

Spence H. (1976), "Product Selection, Fixed Costs, and Monopolistic Competition", Review of Bconomic Studies, June, Vol XLIII(2), no 134, 217-36.

Venables, A. (1982), Optimal Tariffs for Trade in Monopolistically Competitive Commodities, Journal of International Economics 12, 255-41.

Venables, A. (1985), Customs Union, Tariff Reform and Trade in Differentiated Products, Working Paper 38, CEPR, University of Sussex. 
8501C Greenwood, Jeremy and Kent P. Kimbrough. FOREIGN EXCHANGE CONTROLS IN A BLACK MARKET ECONOMY.

8502C Horstmann, Ignatius and James R. Markusen. UP YOUR AVERAGE COST CURVE: INEFFICIENT ENTRY AND THE NEW PROTECTIONISM.

8503C Gregory, Allan $w$. TESTING INTEREST RATE PARITY AND RATIONAL EXPECTATIONS FOR CANADA AND THE UNITED STATES.

8504C Kuhn, Peter, and Ian Wooton. INTERNATIONAL FACTOR MOVEMENTS IN THE PRESENCE OF A FIXED FACTOR.

8505C Wong, Kar-yiu. GAINS FROM GOODS TRADE AND FACTOR MOBILITY.

8506C Weller, Paul and Makoto Yano. FUTURE MARKETS, REAL INCOME, AND SPOT PRICE VARIABILITY: A GENERAL EQUILIBRIUM APPROACH.

$8507 \mathrm{C}$ Diewert, W.E. THE EFFECTS OF AN INNOVATION: A TRADE THEORY APPROACH. 8508C Ethier, Wilfred J. FOREIGN DIRECT INVESTMENT AND THE MULTINATIONAL
FIRM.

8509C Dinopoulos, Elias. INSIDE THE BLACK BOX: (IN) TANGIBLE ASSETS, INTRAINDUSTRY INVESTMENT AND TRADE.

8510C Jones, Richard, John Whalley and Randall Wigle. REGIONAL IMPACTS OF TARIFFS IN CANADA: PRELIMINARY RESULTS FROM A SMALL DIMENSIONAL NUMERICAL GENERAL EQUILIBRIUM MODEL.

8511C Whalley, John. HIDDEN CHALLENGES IN RECENT APPLIED GENERAL EQUILIBRIUM EXERCISES.

8512C Smith, Bruce. SOME COLONIAL EVIDENCE ON TWO THEORIES OF MONEY: MARYLAND AND THE CAROLINAS.

8513C Grossman, S.J., A. Melino, and R.J. Shiller. ESTIMATING THE CONTINUOUS TIME CONSUMPTION BASED ASSET PRICING MODEL.

8514C Romer, Paul R. TAX EFFECTS AND TRANSACTION COSTS FOR SHORT TERM MARKET DISCOUNT BONDS.

8515C MCCallum, Bennett T. ON CONSEQUENCES AND CRITICISMS OF MONETARY TARGETING.

8516C Dinopoulos, Elias and Ian wooton. A NORTH-SOUTH MODEL OF INTERNATIONAL JUSTICE.

8517C Huffman, Gregory $W$. A DYNAMIC EQUILIBRIUM MODEL OF ASSET PRICES AND TRANSACTION VOLUME.

8518C Huffman, Gregory $w$. AN ALTERNATIVE VIEW OF OPTIMAL SEIGNIORAGE.

8519C Huffman, Gregory W. ASSET PRICING WITH HETEROGENEOUS ASSETS. 
8520C Hercowitz, Zvi. THE REAL INTEREST RATE AND AGGREGATE SUPPLY.

8521C Davies, James and Michael Hoy. COMPARING INCOME DISTRIBUTIONS UNDER AVERSION TO DOWNSIDE INEQUALITY.

8522C Clarete, Ramon and John Whalley. INTERACTIONS BETWEEN TRADE POLICIES AND DOMESTIC DISTORTIONS: THE PHILIPPINE CASE.

8523C Nguyen, Trien T. and John whalley. COEXISTENCE OF EQUILIBRIA ON BLACK AND WHITE MARKEIS.

8524C Hamilton, Bob, Sharif Mohammad and John Whalley. APPLIED GENERAL EQUILIBRIUM ANALYSIS AND PERSPECTIVES ON GROWTH PERFORMANCE.

8525C Huffman, Gregory $W$. THE LAGGED EFFECTS OF POLICY ON THE PRICE LEVEL.

8526C Laidler, David. FISCAL DEFICITS AND INTERNATIONAL MONETARY INSTITUTIONS.

8527C Goodfriend, Marvin. MONETARY MYSTIQUE: SECRECY AND CENTRAL BANKING.

8528C Nguyen, Trien T. and John Whalley. GENERAL EQUILIBRIUM ANALYSIS OF PRICE CONTROLS: A TWO-SECTOR COMPUTATIONAL APPROACH.

8529C Heckman, James J. and V. Joseph Hotz. AN INVESTIGATION OF THE LABOR MARKET EARNINGS OF PANAMANIAN MALES: EVALUATING SOURCES OF INEOUALITY.

8530C Greenwood, Jeremy and Gregory W. Huffman. A DYNAMIC EOUUILIBRIUM MODEL OF INFLATION AND UNEMPLOYMENT.

8531C Freeman, Scott. INSIDE MONEY, MONETARY CONTRACTIONS, AND WELFARE.

8532C Paderanga, Cayetano Jr. and Ian Wooton. A POSITIVE VIEW OF INFANT INDUSTRIES.

8533C St-Hilaire, France and John Whalley. A MICROCONSISTENT DATA SET FOR CANADA FOR USE IN REGIONAL GENERAL EQUILIBRIUM POLICY ANALYSIS.

8534C Whalley, John. OPERATIONAIIZING WALRAS: EXPERIENCE WITH RECENT APPLIED GENERAL EQUILIBRIUM TAX MODELS.

8535C Melvin, James R. THE GENERAL NON-EQUIVALENCE OF TARIFFS AND IMPORT QUOTAS. 
8601C Greenwood, Jeremy and R. Preston McAfee. EXTERNALITIES AND ASYMRETRIC INFORMATION.

8602C Dinopoulos, Elias and Mordecha1 E. Krelnin. IMPORT OUOTAS AND VERS: A COMPARATIVE ANALYSIS IN A THREE-COUNTRY FRAMEWORK. 8603C Clarete, Ramon and John Whalley. COMPARING THE MARGINAL WELFARE
COSTS OF COMMOITY. AND TRADE TAXES.

8604C Wigle, Randy. CANADIAN TRADE LIBERALIZATION: SCALE ECONOUIIES IN A GLOBAL CONTEXT.

8605C Parkin, Michael. DOMESTIC MONETARY INSTITUTIONS AND FISCAL DEFICITS.

8606C Dinopoulos, Ellas and Ian Wooton. INTERNATIONAL TRADE AND THE ACQUISITION OF SKILLS.

$8607 \mathrm{C}$ Kawasaki, Selichi and John McMtllan. THE DESIGN OF CONTRACTS: EVIDENCE FROM JAPANESE SUBCONTRACTING.

8608C Williamson, stephen D. LIQUIDITY, BANKING, AND BANK FAILURES.

8609C Grossman, Gene $M$. and Carl Shapiro. COUNTERFEIT-PRODUCT TRADE.

8610C Deardorff, Alan V. WHY DO GOVERNMENTS PREFER NONTARIFF BARRIERS?

8611C Horstmann, Ignatius and James R. Markusen. LICENSING VERSUS DIRECT INVESTMENT: A MODEL OF INTERNALIZATION BY THE MULTINATIONAL ENTERPRISE.

8612C Thursby, Jerry G. and Marfe C. Thursby. BILATERAL TRADE Flows, THE LINDER HYPOTHESIS, AND EXCHANGE RISK.

8613C Clarete, Ramon and John Whalley. EQUIIIBRIUM IN THE PRESENCE OF FOREIGN EXCHANGE PREMIA.

8614C Wooton, Ian. TOWARDS A COMMON MARKET: FACTOR MOBILITY IN A CUSTOMS UNION.

8615C St-Hilaire, France and John Whalley. SOME ESTIMATES OF TRADE FLOWS IN BANKING SERVICES.

8616C Evenson, Robert E. and Cayetano Paderanga Jr. RURAL LABOUR MARKETS, TRANSACTION COST AND PERTIIITY.

8617C Fried, Joel and Peter Howitt. FISCAL DEFICITS, INTERNATIONAL TRADE AND WELFARE.

8618C Trela, Irene, John Whalley, and Randy Wigle. INTERNATIONAL TRADE IN AGRICULTURE: DOMESTIC POLICIES, TRADE CONFLICTS, AND NEGOTIATING OPTIONS. 
8619C Markusen, James $R$, and Anthony J. Venables. TRADE POLICY WITH INCREASING RETURNS AND IMPERFECT COMPETITION: CONTRADICTORY RESULTS FROM COMPETING ASSUNPTIONS.

$8620 \mathrm{C}$ Hunter, Linda and James R. Markusen. PER-CAPITA INCOME AS A DETERMINANT OF TRADE.

8621C Jones, Rich and John Whalley. A CANADIAN REGIONAL GENERAL EQUILIBRIUM MODEL AND SOME APPLICATIONS.

8622C Freeman, Scott, and Gregory W. Huffman. INSIDE MONEY, OUTPUT, AND CAUSALITY.

8623C Hamilton, Colleen, and John Whalley. DEALING WITH THE NORTH: DEVELOPING COUNTRIES AND GLOBAL TRADE NEGOTIATIONS.

8624C Williamson, Stephen D. LAISSEZ FAIRE BANKING AND CIRCULATING MEDIA OF EXCHANGE.

8625C Whalley, John. WHAT HAVE WE LEARNED FROM GENERAL EQUILIBRIUM TAX POLICY MODELS?

8626C Bhatia, Kul B. SHORT RUN AND LONG RUN IN THE THEORY OF TAX INCIDENCE.

8627C Jones, Rich, and John Whalley. REGIONAL EFFECTS OF TAXES IN CANADA: AN APPLIED GENERAL EQUILIBRIUM APPROACH.

8628C Nguyen, Trien T., and John Whalley. GENERAL EQUILIBRIUM WORLD TRADE UNDER BILATERAL QUOTAS.

8629C Clarete, Ramon L., and James A. Roumasset. THE RELATIVE WELFARE COST OF INDUSTRIAL AND AGRICULTURAL PROTECTION POL ICIES USING PHIL IPPINE DATA. 
8701C McMillan, John, John Whalley, and thu Li Jing. INCENTIVE EFFECTS OF PRICE RISES AND PAYMENT-SYSTEM CHANGES ON CHINESE AGRICULTURAL PRODUCTIVITY GROWTH.

8702C Wooton, Ian. CAPITAL, SKILLS, AND INTERNATIONAL TRADE.

8703C RYan, Cillian. TRADE IN THE PRESENCE OF ENDOGENOUS INTERMEDIATION IN AN ASYMMETRIC WORLD.

8704C Kennan, John and Raymond Riezman. OPTIMAL TARIFF EQUILIBRIA WITH CUSTOMS UNIONS.

8705C Feenstra, Robert C., and Tracy R. Lewis. NEGOTIATED TRADE RESTRICTIONS WITH PRIVATE POLITICAL PRESSURE.

8706C Briecher, Richard A. POLICY-INDUCED INFLOWS OF FOREIGN CAPITAL IN THE PRESENCE OF RIGID-WAGE UNEMPLOYMENT.

8707C Harrison, Glenn W., Richard Jones, Larry J. Kimbell, and Randall Wigle. HOW ROBUST IS APPLIED GENERAL EQUILIBRIUM ANALYSIS?

8708C Jones, Richard and John Whalley. REGIONAL BALANCE SHEETS OF GAINS AND LOSSES FROM NATIONAL POLICIES.

8709C Markusen, James R. TRADE IN PRODUCER SERVICES AND IN OTHER SPECIALIZED INTERMEDIATE INPUTS.

8710C Markusen, James R. PRODUCTION, TRADE, AND MIGRATION WITH DIFFERENTIATED, SKILLED WORKERS.

8711C Markusen, James R. INTRA-FIRM SERVICE TRADE BY THE MULINATIONAL ENTERPRISE.

8712C Parkin, Michael. MONETARY POLICY AND AGGREGATE FLUCTUATIONS.

8713C Smith, Bruce D. LEGAL RESTRICTIONS, "SUNSPOTS", AND CYCLES.

8714C Harrison, Glenn W. and E.E. Rutstrom. TRADE WARS AND TRADE NEGOTIATIONS: A COMPUTATIONAL APPROACH.

8715C Smith, Bruce D. MONEY AND INFLATION IN THE AMERICAN COLONIES: FURTHER EVIDENCE ON THE FAILURE OF THE QUANTITY THEORY.

8716C Wonnacott, Paul and R.J. Wonnacott. UNILATERAL FREE TRADE VS. A CUSTOM'S UNION: THE FURTHER SEARCH FOR A GENERAL PRINCIPLE.

8717C Neary, Peter. TARIFFS, QUOTAS AND VOLUNTARY EXPORT RESTRAINTS WITH AND WIYHOUT INTERNATIONALLY MOBILE CAPITAL. 8718C Schmitt, Nicolas. TWO-COUNTRY TRADE LIBERALIZATION IN AN ADDRESS MODEL
OF PRODUCT DIFFERENTIATION. 